\title{
Living in the End Time: Ecstasy and Apocalypse in the Work of H.D. and Janette Turner Hospital
}

\author{
Belinda McKay
}

Despite the current preoccupation with globalisation, literary criticism remains heavily focused on national cultures. In the context of Australian literature, comparisons are regularly made with the literatures of other British Commonwealth nations, but surprisingly infrequently with that of Britain's first and most successful colony, the United States. This article explores thematic and cultural connections between the work of American-born modernist poet and novelist H.D. (1886-1961) and the Australian-born postmodern novelist Janette Turner Hospital (born 1942). It suggests that the transnational phenomenon of ecstatic Protestantism, which originated in northern Europe and was disseminated widely around the globe along the channels of commerce and colonisation, has been a key influence in shaping the literary imaginations of these writers. Indeed, Protestantism - far from being a spent or reactive force - continues to generate new forms of modernity as its emphasis on transformation is exported from somewhat inward-looking religious communities into broader cultural domains.

Both H.D. and Janette Turner Hospital were brought up in the religious environments that form part of the ecstatic Protestant tradition. H.D. is the pen name of Hilda Doolittle, who was born in Bethlehem, Pennsylvania in 1886, spent her adult life in Europe and died in Switzerland in 1961. Her maternal family, who belonged to the Moravian Brethren, migrated to Pennsylvania from Central Europe in the middle of the eighteenth century as part of Count Nikolaus von Zinzendorf's evangelical push to establish radical communal settlements around the world as havens for believers and missions for the conversion of local populations. Bethlehem, Pennsylvania was founded by Zinzendorf himself on Christmas Eve 1741 as the first of a series of American settlements. These Utopian communities broke up the nuclear family and organised members into 'choirs' on the basis of age, sex and marital status: in these choirs, members of the European nobility, freed slaves and Native American converts lived together with remarkable equality. 
H.D. was born into a much more loosely organised religious community led by her grandfather Francis Wolle, a Moravian pastor. Her father, Charles Leander Doolittle, a man of Puritan stock, was a distinguished astronomer, and in 1895 the family moved from the Moravian town of Bethlehem to Upper Darby outside Philadelphia to enable him to take up the Chair of Astronomy and directorship of the Flower Observatory at the University of Pennsylvania. In the absence of a Moravian community, the family worshipped with a Society of Friends (Quaker) congregation, and H.D. attended Friends' Central School in Philadelphia before studying briefly at Bryn Mawr College, which was established by the Society of Friends. H.D. left the United States in 1911, and was based in England and Switzerland for the remainder of her life.

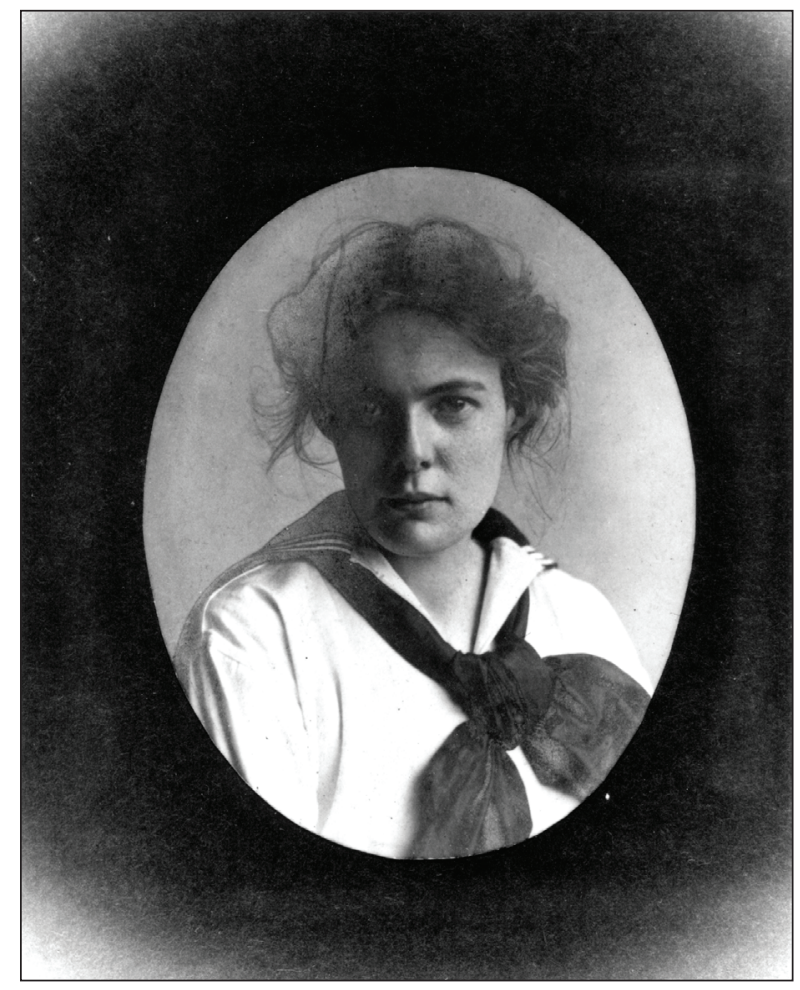

Figure 1: Portrait of H.D.

Source: Belinda McKay.

Janette Turner Hospital, who was born in Melbourne in 1942 but moved to Brisbane at the age of seven, was brought up in the Pentecostal faith. The gospel church to which her family belonged had its immediate origins in the Welsh Revival of 1904-05, which made 100,000 converts within a year and began a global evangelical outreach of a re-radicalised form of Methodism. Turner Hospital has described her maternal Morgan grandfather, who had 'a dramatic conversion on the Western Australian goldfields', as 'a born-again Christian to the core' - 
but, paradoxically, with a 'pagan, Celtic, Welsh core' as well. Her paternal Turner grandfather, by contrast, was 'very English and classically trained ... an intellectual' who told her stories from Greek and Roman mythology. Turner Hospital's father converted from Anglicanism to Pentecostalism during World War II: 'my father lonely in Melbourne and in the Air Force, with the war raging, walks into a little gospel church and suddenly feels that his life could be transformed and that he could feel it all had meaning'. Despite the 'intellectual restrictions' of her upbringing, Janette Turner Hospital recalls that Pentecostalism gave her excellent training in rhetoric, as the 'hellfire and brimstone preachers' sent out from Wales 'really had a sense of art'. She was able to study at the University of Queensland with her father's support, despite the opposition of the rest of the congregation, who argued that if young people went to university they lost their faith. Turner Hospital admits to feeling 'slightly guilty' that they turned out to be right!' Janette Turner Hospital has spent most of her adult life in Canada and the United States. Recently retired as Carolina Distinguished Professor of English at the University of South Carolina, she lives with her husband, Australian-born theologian Clifford Hospital, in Columbia, South Carolina.

Moravianism - which is one of the oldest forms of Protestantism and considerably predates Luther - had a profound influence on John Wesley, and through Methodism was one of the roots of Pentecostalism. ${ }^{2}$ Moravianism, Methodism and Pentecostalism all form part of an emotional, evangelical, participatory and egalitarian Protestant tradition that found particularly fertile ground in the United States, but which as David Martin argues - was an important influence on all of Britain's settler dispossessory colonies:

All the peripheries of Britain are more Protestant and egalitarian than England itself, and have contributed massively to the cultures of the 'white' Commonwealth and to the foundation of America ...

Although the influence of Protestantism on the shaping of American culture receives considerable ongoing scholarly attention, there is surprisingly little research on the role of Protestantism on the formation of Australian culture. Despite her own loss of faith, and her awareness of 'how quickly things that begin as liberating and empowering turn into their own systems of oppression and rigidity', Janette Turner Hospital expresses irritation at

the glib ways in which white academics and intellectuals within Australia, knowing zilch about it, dismiss fundamentalism as a totally oppressive system. It certainly can easily become that, but the reason Pentecostalism is growing hugely in the world, especially in South America and in Africa, and the reason the black church is huge here [in the southern United States] is because it is a form of empowerment to marginalised people initially, and I don't feel that anybody in intellectual and academic circles has any inkling about that. ${ }^{4}$ 
In response to Turner Hospital's justified criticism of the lack of serious interest in non-conformist Protestantism in Australia, this article sketches out some of the ways in which Protestant traditions and practices can provide a form of empowerment, by exploring the work of two women writers.

As Turner Hospital points out, the term 'fundamentalism' - which suggests doctrinal narrowness and general oppressiveness - is often used as a pejorative blanket term to characterise Pentecostalism and similar sects. However, in this context the term 'ecstatic Protestantism' is more appropriate, as it better suggests some of practices and features that have been empowering to writers. In addition to elements found broadly across all Protestant churches - including the internalisation of conscience and an emphasis on self-scrutiny - ecstatic versions of Protestantism share an emphasis on an emotional 'heart religion' (herzen Religion in German), where the body itself may become a site and sign of transformation through phenomena like quaking, shaking or falling. The world inhabited by believers is replete with 'signs and wonders' to be interpreted as signifiers of God's plan for the individual or community. God also bestows spiritual gifts, or charisms, such as 'healings, helps, governments, diversities of tongues' (1 Corinthians 12:28). The early Moravians thus cast the lot to appoint new ministers, ${ }^{5}$ and occasionally spoke in tongues. This latter phenomenon - glossolalia - has become central to Pentecostalism, deriving from the first Pentecost as recorded in Acts 2:2: 'And suddenly there came a sound from heaven as of a rushing mighty wind, and it filled all the house where they were sitting.' As David Martin puts it, for Pentecostalists, "signs form part of a complete "field" which is integrated around the key notion of transformation'. ${ }^{6}$ Transformation occurs most dramatically in the conversion experience, the New Testament model for which is St Paul's conversion on the road to Damascus, as recorded in Acts 9.

In The Rise of the Novel, Ian Watt has demonstrated the extent to which the subjective, individualist and introspective qualities of Protestantism contributed to the rise of the novel in the eighteenth century. His work also suggests that elements of Protestant belief and practice tend to migrate into new cultural domains, detaching themselves from the spiritual domain: 'we can say of [Defoe],' he writes, 'as of later novelists in the same tradition, such as Samuel Richardson, George Eliot or D.H. Lawrence, that they have inherited of Puritanism everything except its religious faith'. ${ }^{7}$ The adaptability of Protestantism to new spheres is also demonstrated by Max Weber's thesis in relation to capitalism. ${ }^{8}$ Indeed, it is hardly possible to over-estimate the role of Protestantism in shaping the modernity of contemporary Anglophone cultures such as those of the United States and Australia.

Both H.D. and Janette Turner Hospital distanced themselves from the religious contexts of their childhoods in order to become writers: neither of them incorporated any conventional religious belief or practice into her adult life, and their physical migrations - H.D. to Europe and Janette Turner Hospital to North America reinforced the inner movement from a somewhat circumscribed faith to broader spiritual and intellectual horizons. ${ }^{9}$ Nonetheless, following Watt, I suggest that as writers they have inherited of their ecstatic Protestant backgrounds everything except the religious faith. In other words, H.D. and Turner Hospital transpose key 
elements of their formative Protestant identity from the spiritual domain to the domain of the literary imagination. As Turner Hospital has observed, her writing is about exploring 'transformative moments', and the role of the ecstatic impulse behind such moments is the first area that I will look at in the work of these two writers. $^{10}$

H.D.'s Imagist poems were in the vanguard of modernism in English when they began to be published around 1912. Even today, they remain somewhat enigmatic: as J.B. Harmer once observed, 'there is often an intensity disproportionate to the apparent situation'. ${ }^{11}$ This intensity frequently manifests itself as wind, which is reminiscent of the 'rushing mighty wind' of the first Pentecost, as well as similar concepts in other spiritual traditions; it is also, of course, the poet's vital breath. Wind annihilates the lifeless beauty of gardens, but vibrates through the wild landscapes where H.D. seeks a new beauty. In her novel Bid Me to Live (1960), H.D. wrote of wind as 'a visible Presence ... an inhuman element, a divine element'. ${ }^{12}$ This divine energy also swirls through H.D.'s earliest poetry - for example, in the poem 'Garden':

$\mathrm{O}$ wind, rend open the heat,

cut apart the heat,

rend it to tatters ...13

Everywhere, H.D.'s Imagist poetry bears the marks of invisible but powerful spirit forces, which have often been read as the presence of ancient Greek gods and demiurges. Some contemporary reviewers, however, understood that there was a more complex - though elusive and not conventionally Christian - theology at work in the poems. English novelist May Sinclair attributed to H.D.'s poems a 'divine quality' in their suggestion of 'unspeakable mysteries'. ${ }^{14}$ Other critics described H.D. as a 'mystic' in recognition of the intensity and inwardness of her Imagist poems. ${ }^{15}$ The Hellenism of H.D.'s work has received a good deal of critical attention, but the Moravianism of her work (and its intersection with Hellenism) remains under-researched. ${ }^{16}$

H.D.'s experimental prose of the 1920s draws more explicitly than her poetry on elements of her Moravian background. In a general sense, her early prose has many elements in common with the tradition of confessional autobiography that developed in Protestant journals. The confessional autobiography provided a model for the first English novel, Defoe's Robinson Crusoe; it also influenced the rise of Romanticism through Rousseau, and was the mode that first gave visibility to women writers in the eighteenth and early nineteenth century. The confessional mode of H.D.'s prose, however, owes a specific debt to the Moravian custom that required each member of the congregation to write a memoir. ${ }^{17}$ Although the practice had become attenuated by the time of H.D.'s birth in 1886, her work owes much to the model of self-consciousness found in these memoirs, which are both introspective and relational (designed to be read by others), and are organised around the transformative moment of a spiritual conversion. The specific catalyst for H.D. to turn to introspective prose, however, was a modern form of selfscrutiny - psychoanalysis, which became a major force in her life and work. She 
was introduced to Freud's work by Havelock Ellis, and from 1931 participated in analysis with five different analysts, including Freud himself (an experience she recorded in her memoir Tribute to Freud). ${ }^{18}$

A number of H.D.'s autobiographical novels, which remained unpublished during her lifetime, explore the twin issues of lesbianism and creativity by using a model of the authority of individual revelation, which owes as much to Moravianism as to psychoanalysis. The novels vibrate with signs, wonders and gifts that are completely disengaged from any Christian religious function and mobilised instead for personal and creative ends. In writing about her first lesbian relationship, with writer Frances Gregg, H.D. repeatedly draws on the conversion of St Paul. For example, in Paint It Today, H.D. writes of her first meeting with Josepha (a character based on Frances Gregg) that 'there came as to Paul of Tarsus, light'. ${ }^{19}$ The reference is to Acts 9:3: 'And as he journeyed, he came near Damascus: and suddenly there shined round about him a light from heaven ...' Paul's change of name from Saul might also be significant in H.D.'s adoption of the enigmatic and genderless initials as her pen name. Distraught at the publication, without permission, of her photograph for the first time in 1923, she elucidated the significance the initials held for her: 'The initials, H.D. had no identity attached; they could have been pure spirit. But with this I'm embodied!'20 To become a writer was to be born again.

In another early novel, HERmione, H.D. ascribes her awakening to a full awareness of her artistic vocation to meeting Fayne (another character also based on Frances Gregg). At the end of the novel, Her walks alone across snow-covered fields. She sees the expanse of snow as a world 'razed' for her to create anew: the landscape is 'virginal for one purpose, for one Creator ... [T] he creator was Her's feet, narrow black crayon across the winter whiteness.' She likens herself to a star in daylight - invisible to the bodily eye. It is an epiphany of the visionary Fayne/Frances that transforms Her's way of seeing, enabling her to realise fully her vocation as poet-prophet:

When she said Fayne a white hand took Her. Her was held like a star invisible in daylight that suddenly by some shift of phosphorescent values comes quite clear. Her saw Her as a star shining white against winter daylight. ${ }^{21}$

For H.D., the star symbolised the being who was marked out for a special destiny due to the possession of the spiritual gifts of vision and prophecy. In her memoir, The Gift (written in London during World War II when she was renewing her interest in the Moravian heritage), she recounts that a gypsy had predicted to her mother Helen the coming of an especially gifted child who would be 'born under a star'. ${ }^{22}$ H.D., who was born in Bethlehem, Pennyslvania, identified her birth as the fulfilment of that prophecy. This is a rather creative take on Moravian theology - somewhere between justification by faith and actually asserting godhead - but it is not entirely without precedent in Moravian women's journals: Benigna Zahm (1748-1804) writes that in 1772 the Saviour 'had assumed our mortal frame in the body of a young virgin' (herself) and that she was 'able to enjoy and benefit in body and soul from all the blessings that lie in His holy incarnation'. ${ }^{23}$ 
H.D. received three key legacies from the herzen Religion of Moravianism: first, the ecstatic pietist belief in the reality of things unseen; second, a belief that love is the spiritus universalis that will unite all religions; and third, a conviction that the recovery of repressed spiritual traditions held the secret to the spiritus universalis. Her particular contribution as a writer was to renew and transform these legacies through her passionate engagement with new cultural phenomena such as psychoanalysis and film.

For Janette Turner Hospital, signs and wonders are even more ambiguous and deceptive than they are for H.D., but nonetheless they fill the pages of her novels and stories, and are again intimately linked to her vocation as a writer. This is perhaps most clearly articulated in the autobiographical short story 'Morgan Morgan'. Grandpa Morgan, a breeder of dahlias, is a Welshman and a Pentecostal convert. He introduces his granddaughter to a world of signs and wonders, promiscuously blurring the distinction between the worldly and the spiritual, and causing Grandma Morgan to observe that the child will 'never know the difference between truth and lies'. ${ }^{24}$ Reminiscing about his experiences on the goldfields before his conversion, he recounts his blinding Pauline vision of finding a nugget as big as a man's fist and tells his granddaughter, 'I ... put it right back down where I found it, inside the vision.' (CS 164) Like Paul, who was blinded for three days after his vision of Christ (Acts 9), Morgan Morgan is nearly blinded when sunlight strikes the nugget. By such signs he has come to see himself as a man of destiny, and he tells his granddaughter that the Morgan nugget is waiting 'for one of us to find it again' ( $C S$ 165). In the story, he passes on this sense of destiny or spiritual giftedness to his granddaughter, who will find the nugget again through writing.

On Sundays in the gospel church, the Spirit is a wind that '[blusters] and [rushes] through' Grandpa Morgan (CS 169), causing him to shout 'hallelujah' and sending 'seismic' shocks (CS 170) through the man in the pew in front of him:

The shock waves hit Mr Peabody sharply in the nape of his neck and travelled down his spine with such force that he would rise an inch or two from the pew. Most of his body would go rigid, but his head and his hands would quiver for seconds at a time, Glory, glory he would murmur in a terror-stricken prayerful voice.

Not surprisingly, it is here in the chapel that the narrator has her first ecstatic experience:

But then came the day that a shaft of sunlight fell from a high amberglass window in the church and placed a crown of gold on Mr Peabody's head. 'Oh!', I gasped aloud. 'Look!' And Grandpa shouted Hallelujah! And Mr Peabody rose up into his corona like a skyrocket and I saw a million doves and the gilded petals of all the dahlias in the world rising up into the pointed arch in which God lived. (CS 169-70) 
Initially, the pastor is convinced that the young girl has seen the Holy Spirit, but not everybody is so sure: "She makes things up," my Sunday School teacher insisted. "She handles the truth very carelessly. She believes her own lies." (CS 170)

The scepticism of the Sunday School teacher destabilises the narrator's belief in her vision, despite Grandpa Morgan's reassurance that she did indeed see doves with gold wings. He also reassures her that the story of the Morgan Nugget is true, but the narrator has been awakened not simply to the power of transformation but also to the ambiguity and deceptiveness of signs: an irrevocable break in faith accompanies the awareness that not all ecstatic visions originate from God. In 'Morgan Morgan', Janette Turner Hospital shows us the moment at which signs and wonders become dislocated from the Pentecostal spiritual context and spill into the secular domain of the creative imagination. The consolation implicit in the story is that ecstasy can be experienced by 'making things up'. This story is a parable of how Janette Turner Hospital became a writer.

The second area where H.D. and Janette Turner Hospital reveal their debt to ecstatic Protestantism is in their literary response to the problem of living in apocalyptic times. Although H.D.'s family was less preoccupied on a daily basis with the imminence of the Second Coming than Turner Hospital's, both Moravianism and Pentecostalism promote a sense that believers are living in the 'last days' - in other words, that they occupy a liminal space of heightened awareness, and exist in a state of 'becoming'. In an interview, Turner Hospital recalls her childhood experience of living in the end time:

When you grow up in a fundamentalist world you actually grow up in a mythic narrative space because everything in the Old Testament has immediate relevance and you read it at the dinner table, so in a way you grow up in timeless space. You grow up with a 'God's eye' view of time because you always know that the Second Coming could be tomorrow or next week. Every Sunday you are told that you are living in the end time. There's always this feeling that at any moment God is going to put mankind to account $\ldots{ }^{25}$

Growing up with a sense of living in the end time is an experience to which she returns frequently in her writing. In her story 'After Long Absence', the protagonist/narrator gives a powerful impression of what it is like to live in a house where 'nothing has ever been secular' (173): as the mother washes the dishes in 'water just on the leeside of boiling', the narrator glances at the Biblical text in needlepoint on the wall, 'He shall try you in a refiner's fire' (172). This allusion to Malachi 3:1-3 reminds us of the need to be prepared for the arrival of the 'messenger of the covenant': 'But who may abide the day of his coming? and who shall stand when he appeareth? for he is like a refiner's fire, and like fullers' soap.' The New Testament version of the Second Coming, however, emphasises the spiritual gifts that will be bestowed on believers:

And it shall come to pass in the last days, saith God, I will pour out of my Spirit upon all flesh: and your sons and your daughters shall prophesy, and your young men shall see visions, and your old men shall dream dreams ... (Acts 2:17) 
Prophecies, visions and dreams - the stuff of ecstatic Protestantism - are equally the stuff of literature. Later in life, in response to apocalyptic events, both writers return to Protestant habits acquired in their childhoods of scrutinising the self and the world, interpreting the signs, preparing oneself, seeing in visions and prophesying.

H.D. lived in London during the two World Wars, each of which triggered in her a severe mental breakdown. During World War II, as the bombs rained upon London, she wrote three long poems that were later published as Trilogy: 'The Walls Do Not Fall', 'Tribute to the Angels', and 'The Flowering of the Rod'. Nowhere is the enduring power of her Moravian inheritance as directly evident as in Trilogy, where H.D. acknowledges herself as one of the 'latter-day twiceborn' (CP 521). Here, Spirit manifests itself amidst the death and destruction of the bombed city:

ruin everywhere, yet as the fallen roof

leaves the sealed room

open to the air,

so, through our desolation,

thoughts stir, inspiration stalks us

through gloom:

unaware, Spirit announces the Presence;

shivering overtakes us,

as of old, Samuel ... (CP 509-10)

London has been through 'Apocryphal fire', but the initiates pass through the flame and are saved for a purpose of which they are as yet unaware.

Every object in Trilogy is infused with spirit: the prima materia of art, like that of alchemy, is all around, waiting to be transmuted into 'spiritual' reality which is the 'one-truth' ( $C P$ 537). In Trilogy, the Holy Ghost is revealed to the poet as Love, and H.D. conceives of her poetic role as revealing the spirit of love, which is the light in human darkness. She traces all the manifestations of the spirit of love, bringing together all religious traditions as if evoking the legions of light against darkness. In the end, there is for H.D. only one unified tradition in which there is neither male nor female, pagan nor Christian, but only the healing truth of love. It is the presence of the Holy Ghost that enables writers to reforge the lost links with this ancient wisdom:

we are the keepers of the secret,

the carriers, the spinners

of the rare intangible thread

that binds all humanity

to ancient wisdom,

to antiquity ... (CP 523)

Janette Turner Hospital, too, is preoccupied by the survival of the human spirit in the face of cataclysmic events. Her novel, Due Preparations for the Plague (2003), which traces the effects on survivors of an act of terrorism, was begun before 
September 11, 2001, but completed afterwards. As the title of the novel suggests, Turner Hospital is exploring whether it is possible to make 'due preparations' for cataclysmic events - a theme taken up again in her latest novel, Orpheus Lost (2007), which takes the reader forward to the war on terror and back to Vietnam and the Holocaust through the framework of Greek myth.

Due Preparations for the Plague is a novel in which powerful invisible forces shape human lives. Two intelligence agents, an Arab and an American, both have code names beginning with ' $S$ '. Sirocco and Salamander epitomise the labile, deceptive quality of signs in much of Turner Hospital's work: while their code names and attributes suggest that they are spirit messengers in some sense, it is unclear whether the destruction that they wreak in any way serves to purify their victims into an 'offering in righteousness' (Malachi 3:3) or whether, in the (post) modern world, all messengers are fallen angels. Sirocco is 'the desert wind that scorches where it blows' ${ }^{26}$ - an association with the Pentecostal 'rushing mighty wind' that brings 'cloven tongues like as of fire' (Acts 2: 2-3). The American agent Salamander, named for the mythical Luciferian creature who can survive flames, attempts to channel the 'madness of true believers' such as Sirocco 'in the interests of global stability for the greater good of all' (DP 226). Nevertheless, it is Salamander who unwittingly sets in motion the chain of events that leads to the hijacking in 1987 of Air France Flight 64 and the destruction of all passengers except for the children who, like H.D.'s initiates, pass through the flame and are saved for a purpose of which they are at first unaware.

Due Preparations is the story of how one of these child survivors, Samantha Raleigh, with the help of Salamander's son and daughter, pieces together the mystery of AF 64 from fragmentary pieces of evidence (intelligence files, recollections, tapes, an encrypted journal) that resurface thirteen years after the plane was hijacked. David Callahan has argued that Janette Turner Hospital's work exemplifies existence as interpretation:

From family history and academic training, Hospital has been exposed to a view of reality as having been written by God, in which nothing and no possible connection can be without significance, for how could God create anything that was meaningless or insignificant? ${ }^{27}$

In Due Preparations, the ecstatic Protestant habit of reading the signs written on to the world is brought into a postmodern context. The novel also intersects with postmodern concerns in its interest in the use of sub-rational ways of knowing and also of responding to crises in espionage. The CIA agent Salamander recommends the practice of something akin to the state of 'disembodied ecstasy' that H.D. used in war-torn London:

When in extremis, close eyes, open mind, step out into uncharted abysses of your own memory and imagination, open parachute, create a floating world, explore in tunnels and byways, stay there until All Clear sounds. (DP 262) 
One of the most chilling and ambiguous aspects of the novel is the way in which practices developed in various spiritual traditions are taken up by CIA agents and terrorists, and prove to be remarkably effective in empowering them to carry out acts of destruction.

In Due Preparations for the Plague, Janette Turner Hospital, like H.D., turns to 'ancient wisdom' as a way of understanding catastrophic events, and of preparing oneself - to the extent that preparation is possible - for the next crisis. In the final chapter, Samantha experiences a brief but illusory moment of peace. The reader knows that September 11, 2001 is only three weeks away, rendering Samantha's questions, which conclude the novel, especially poignant: ' $[\mathrm{H}]$ ow do we ready ourselves for what might happen tomorrow? What possible preparations can be made?' The novel's answer is to point to a prophetic literary tradition dealing with the survival of earlier human crises, such as Defoe's A Journal of the Plague Year, Boccaccio's Decameron and the Essene Gospels. As Mather Hawthorne, alias Salamander, tells his son:

Think of it, Lowell ... a message sent through twenty centuries of time. What does that tell us about the desperation and faith of the Essenes? ... It tells us that the truth will endure, Lowell. Even if you kill the messenger, it tells us, a dangerous message can hide and bide its time until the message can safely be read. (DP 175)

The novel ends with Samantha discovering the truth about her own personal history as she sits on a grave behind St Paul's Chapel, the oldest extant church in Manhattan. Located opposite the eastern side of the World Trade Center, the chapel survived the attack on the Twin Towers without so much as a broken window - just as St Paul's Cathedral in London survived the World War II German bombings that inspired H.D.'s The Gift and Trilogy.

The past, it seems, holds messages for us, if only we are capable of interpreting them. Ultimately, what this comes down to in the case of both writers is faith not so much in the Word, as in words - as both the vehicle for the transmission of messages and as the means through which humans can attempt to interpret the world. Both H.D. and Janette Turner Hospital construct densely allusive, syncretistic texts, forging links between different times and places through palimpsests, as if drawing on the extant traces of past prophecy and renewing prophecy in the present. ${ }^{28}$ The writer-prophet, though flawed and sometimes led astray by false or misleading signs, nonetheless provides the only orientation possible for individuals living through cataclysmic upheaval.

In this article, I have suggested that H.D. and Janette Turner Hospital were both formed as writers by their early exposure to ecstatic Protestantism. Once acquired, the habit of transformation practised by Moravians, Pentecostals and other ecstatic Protestants - seeing the ordinary world as replete with signs and wonders that render it extraordinary; undergoing conversion from one state to another; experiencing the body as a site and sign of inner changes - is addictive. Both H.D. and Janette Turner Hospital, like William Blake, whose parents were 
part of a Moravian congregation in London, ${ }^{29}$ discovered the trick of transposing key elements of their Protestant identity from the spiritual domain to the domain of the literary imagination. Modernism may owe a particular debt to Protestantism, since Ezra Pound and T.S. Eliot were also brought up in branches of what David Martin has characterised as 'a voluntary, lay, participatory and enthusiastic faith', which values the potency of individual initiative and the centrality of personal experience and experiment. ${ }^{30}$

There is reason, then, to suggest that in the twentieth and twenty-first centuries, Protestantism - which Watt has shown to be a key element in the emergence of the novel in English - retains its potential to function as an incubator of modernity, as I have sketchily outlined here in relation to the modernism of H.D. and the postmodernism of Janette Turner Hospital. Perhaps because Protestantism - especially of the ecstatic variety - is often associated with conservative political and social positions, the continuing influence of this transnational phenomenon tends to be largely ignored in cultural criticism. However, more detailed studies of ecstatic Protestantism as an historical and contemporary global phenomenon may allow us greater insight into the patterns of flow and connection between colonial and postcolonial cultures, as well as the negotiation of tradition and modernity by writers and other artists in these cultures.

\section{Notes}

1 Belinda McKay, 'Transformative Moments: An Interview with Janette Turner Hospital', Queensland Review 11(2) (2004): 6, 8, 9. The interview was conducted on 7 November 2003.

2 Moravianism traces its roots back to Jan Hus and sometimes beyond. A group of Brethren formed in Bohemia in 1457 had attracted widespread support of the population by the middle of the sixteenth century, but was forced underground after the Thirty Years' War. In 1772, a small group of Brethren from Moravia were given refuge on the Saxon estate of the pietist Count Nikolaus von Zinzendorf. Under Zinzendorf's leadership, Moravianism became a significant transnational religious movement. For the impact of Moravianism on John Wesley, see John Telford, The Life of John Wesley (New York: Hunt \& Eaton and Cincinnati: Cranston \& Curtis, n.d.), 77-80. Wesley was attracted by the deep faith of the Moravians, and by the religion's emphasis on the transformation of the emotional life of the believer.

3 David Martin, Tongues of Fire: The Explosion of Protestantism in Latin America (Oxford: Blackwell, 1990), 19.

4 McKay, 'Transformative Moments': 7.

5 Following Proverbs 16:33.

6 Martin, Tongues of Fire [163].

7 Ian Watt, The Rise of the Novel: Studies in Defoe, Richardson and Fielding (Berkeley, CA: University of California Press, 1957), 85.

8 H.D.'s grandfather, Francis Wolle (1817-93), provides a good example of Weber's thesis in action. Wolle was brought up in the Moravian townships of Nazareth and Bethlehem, Pennsylvania. While working as a clerk in his father's grocery store, he invented and patented the first machine for making paper bags. Wolle became a teacher and principal in Moravian schools, and was ordained in the Moravian church in 1861. He was also a noted botanist, who published three books on algae. 
9 During World War II, H.D. began to explore the history of Moravianism in a serious way, and in the 1950s she incorporated some Moravian prayer practices into her extremely syncretic spiritual regime.

10 McKay, 'Transformative Moments': 10.

11 J.B. Harmer, Victory in Limbo: Imagism 1908-1917 (London: Secker and Warburg, 1975), 142.

12 H.D., Bid Me to Live (London: Virago, 1984 [1960]), 159.

13 H.D., Collected Poems of H.D.: 1912-1944, ed. Louis L. Martz (New York: New Directions and Manchester: Carcanet, 1984), 25. Subsequently $C P$.

14 May Sinclair, 'The Poems of H.D.' [review of Hymen], The Dial, 72 (February 1922): 203, 207, 206.

15 See John Gould Fletcher, 'H.D.'s Vision' [review of Sea Garden], Poetry, 9 (1927): 266-67; H[arriet] M[onroe], 'H.D.,' Poetry, 5 (1925): 272. See also Richard Aldington, 'A Young American Poet', The Little Review, 2 (1915): 22-25.

16 See Ellen Gregory, H.D. and Hellenism: Classic Lines (Cambridge: Cambridge University Press, 1997).

17 See Katherine M. Faull, ed. and trans., Moravian Women's Memoirs: Their Related Lives, 1750-1820 (Syracuse, NY: Syracuse University Press, 1997).

18 H.D., Tribute to Freud (Boston: David R. Godine, 1974). See also Susan Stanford Friedman, ed., Analyzing Freud: Letters of H.D., Bryher and Their Circle (New York: New Directions, 2002). H.D. began analysis in London in 1931 with Mary Chadwick, and continued with Hanns Sachs, before being accepted by Sigmund Freud on Sachs' recommendation. She was analysed by Freud for five months early in 1933, and then for several more months in 1934. She then continued analysis with Walter Schmideberg in London during World War II, and with Erich Heydt in Switzerland in the 1950s.

19 H.D., Paint It Today, ed. Cassandra Laity (New York: New York University Press, 1992), 7.

20 Francis Wolle, A Moravian Heritage (Boulder, CO: Empire Reproduction and Printing Co., 1972), 58.

21 H.D., HERmione (London: Virago, 1984 [1981]), 223, 225

22 H.D., The Gift: The Complete Text, ed. Jane Augustine (Gainesville, FL: University Press of Florida, 1998).

23 Benigna Zahm in Faull, Moravian Women's Memoirs, 22.

24 Janette Turner Hospital, Collected Stories: 1970-1995 (St Lucia, Queensland: University of Queensland Press, 1995), 167. Subsequently CS.

25 McKay, 'Transformative Moments': 7.

26 Janette Turner Hospital, Due Preparations for the Plague (Sydney: HarperCollins, 2003), 301. Subsequently $D P$.

27 David Callahan, Rainforest Narratives: The Work of Janette Turner Hospital (St Lucia: University of Queensland Press, 2009), 10.

28 Both H.D. and Janette Turner Hospital explicitly draw on the image of the palimpsest, a parchment or paper that has been reused, so that the original writing has been effaced or erased, and written over. H.D. used it as the title of a book of three stories: H.D., Palimpsest (Boston: Houghton Mifflin, 1926). The image of the palimpsest encapsulated her understanding of her literary mission as the recovery and reintegration of lost or repressed traditions of knowledge, in order to make manifest the spiritus universalis.

29 See Keri Davies, 'The Lost Moravian History of William Blake's Family: Snapshots from the Archive', Literature Compass 3(6) (2006): 1297-1319.

30 Martin, Tongues of Fire, p 274. 